\title{
Assessing the effectiveness of Vocational Education and Trainings (VET) in Improving Employability: A Case Study of Skills for Employment Programs in Nepal
}

\author{
Prof. Uma Kant Silwal ${ }^{1}$, Kushmakar Bhatta ${ }^{2}$ \\ ${ }^{1}$ Tribhuban University, Kathmandu, Nepal \\ ${ }^{2} \mathrm{Ph} \mathrm{D}$ Scholar, Mewar University, India
}

\begin{abstract}
Education has tremendous scope as an instrument of socio-economic change. Through education knowledge is imparted and skills, interests, attitudes, aspirations and values are developed which contributes to promote socio-economic status. The purpose of this paper is to examine the effectiveness of Vocational Education and Training (VET) programs in job creation among youths in Nepal. The problem of this study is to ascertain the potency of VET in poverty reduction through engagement in self or wage employment among youths in Nepal. The area of study comprises of the six semi-urban districts of the country in two different occupations; Mason and Solar PV Technician. Descriptive survey design was employed for the study with a population of 226Vocational Education and Training (VET) graduates. Four research questions were formulated and analyzed using arithmetic mean method. The finding of this study revealed that vocational education and trainings can play a vital role in equipping, building and making our youths self-employed, reliable and employable in an industry or company. The study also found that vocational training programs are effective in contributing socioeconomic development and poverty reduction. However, the paper recommends that one of the ways by which government should generate employment and reduce poverty is to focus on a functional, technical and vocational education. Relevancy of the trainings and linkages with employment market is to be increased through market study and revising the existing curriculum.
\end{abstract}

Keywords- Vocational, Occupation, Employment, Gender, Ethnicity.

\section{INTRODUCTION}

Economic growth and social development of a country mostly depends upon the education system of that particular country (Sreenivasulu, 2013). According to AmartyaSen, poverty situation can be improved by focusing not only on generating economic growth, but, more importantly, by enhancing people's capabilities (Sen, 1983). Educational transformations are always the result and the symptom of the social transformations in terms of which they are to be explained (Durkheim, 1915). The alarming rate of youth unemployment in most of the developing countries throughout the globe rises in the recent years. Out of many reasons, lack of trainings, adequate marketable skills and linkages between labor market and skilled youth are some of the major reasons (Mane, 2014). Therefore, relevance quality education is today's need as it is the development of intellectual skills and knowledge which will equip learners to fulfill the needs of the employment market.

Nepal Labour Force Survey (NLFS) 2008 has estimated that in Nepal, out of the total 14.4 million aged 15 and over people, 12.03 million people are economically active. Although it is estimated that 235 thousand people are unemployed, 30 percent of the economically active population is under-utilized and 46 percent of them are 2024 age group population. As a result of a decade long conflict and political instability, over the past 10 year the average growth of GDP has remained to only to 4 percent and industrial growth rate has averaged to only to 0.3 percent (GON, 2015). In such political and economic turmoil, the employment opportunities have also shrunk considerably. The available data shows that over 354,000 Nepalese youths have migrated to foreign employment in the FY 2067/68 and 294,094 in previous year (GON, 2015). Out of them, almost 70 percent youths have migrated without taking any skill related trainings and they are compelled to work 3 Ds (danger, difficult and dirty) jobs.

On the other hand, the available data also indicates that 46.67 percent of the population aged 15 and over (14.4 million) has never attended school. In addition, 10.75

Page $\mid 131$ 
percent, 13.49 percent and 8.87 percent of this age group has completed below primary, primary and lower secondary education respectively (MOE, 2015). People from the rural areas migrate to the urban centers in search of employment opportunities. It has been estimated that the size of such migrating population is around 400,000 in each year. Majority of the migrants do expect to land a job and employment, whereas they do not possess any technical skills. The foreign employment migration, particularly to the Middle East and East Asia is largely because employment opportunities within the country are limited. On the other hand, there is a greater degree of shortage of skilled labour force within the domestic labour market (CTEVT, 2016).

Vocational education has gradually been extended over the years suggests that successive governments see it as playing an important role in our society, especially in getting children ready for work and providing them with the type of skills our economy needs (Zgaga, 2005). It is also clear that a number of children simply are not suited to a purely academic education. Similarly the industries have labor shortage for production and economic growth. In this case expansion of the vocational programs seems to be contextual especially in the developing countries to manage the youth employment (UNESCO, 2012).

The Constitution of Nepal (2015) has provided statutory mandate for the expansion of educational services across the country. As a response to the aspirations of the people and in line with the spirit of the Constitution, the Ministry of Education has emphasized to apply following guideline and principles to provide easy access to education and vocational training to the mass populace (GON, 2016):

* Establishment of education and training as a human right and as a means for bringing positive social changes and empowering people;

* establishment of linkages between education and development;

* equity-based and inclusive education;

* collaboration between various education development partners;

* harmony in the donors' support; and

* adoption of reform an ongoing process.

The government of Nepal has formulated its national policies by emphasizing more to create employment and self-employment opportunities by clearly spelling out its strategy to streamline the vocational trainings as one of the prioritized programs (GON, 2012). In line with the policies and plans, the Three Year Plan (TYP) has emphasized as one of the prime objectives to create decent and ample employment and self-employment opportunities for its citizens within the country.

Council for Technical Education and Vocational Training (CTEVT) is the apex body. Donor supported projects offer vocational training and the CTEVT constituent institutions, private sector training organizations and some of the nongovernment organizations implement the trainings. Their coverage is still limited against the number of unskilled and unemployed workers that enter into the labor market every year (MOE, 2016). In one hand, the country has huge deficiency of skilled workers. On the other, there are virtually limited programmes catering to the need of out-ofschool youths, who are unemployed. These situations pose challenges to bring the out-of-school children into the mainstream and linking them with employment. The Government has invited different stakeholders (particularly, support organizations, local service organizations, private sector, I/NGOs and media) to contribute to TEVT at central and local levels. Emphasis has been placed to initiate participatory planning and implementation approaches while designing and organizing vocational trainings (CTEVT, 2016).

\section{Emphasis on Employment-Oriented Training}

Nepalese education system is hardly tied up with meaningful employment opportunities. As a result, the country meets large number of unemployed graduates in the white collar job sector in one hand and no competence among those who left school before School Leaving Certificate (SLC) on the other (CTEVT, 2012). The youths, who dropped out from the school for various reasons do not have access to acquire skills for employment (MOE, 2016). This further leads them to remain neglected from the "World of Work". As these youths miss gainful employment opportunities, they simply lead poverty to prevail. Their needs and aspirations are unmet and their productive potentials are not properly utilized for the prosperity of country (Sharma, 2008).

\section{Objectives of the Study}

Overall objective of the study was to find out employment status of graduates who are vocationally trained under Skills for Employment Programs in Solar PV Technician and Mason. Specific objectives related to this overall objective are:

* To find employment status of the training graduates for selected trade;

* To assess the quality of training packages contributing to make the graduates skillful for market friendly employment opportunities; 
* To identify types employment absorbing the graduates (e.g. domestic wage employment, domestic selfemployment and foreign employment);

* To find out earning level of the employed graduates; Significance of Study

Transformation of skills into employment demands is associated with the delivery of good quality training as well as post-training supports (Visscher, 2009). Aiming to facilitate and maintain good quality training, Council for Technical Education and vocational Training (CTEVT) has been massively implementing vocational skills training in Nepal from 2005 collaborating with international development agencies. To justify the value of money invested in vocational training to measure the overall outcomes of the project is significantly important. This kind of study would contribute to know employment status of the training graduates in labour markets with the effectiveness of the programs in socio-economic development. It also helps to identify the major hindrances that have been affecting the trainees to be employed in the labour market. It would also provide information regarding improvements required in future undertakings and adjustments to be made within the vocational training programmes to become more effective and results oriented. Further, it would facilitate training providers to learn best ways to proceed with forthcoming training programmes.

\section{Focus Questions for the Study}

Regarding to this study, following research questions were developed and it is attempted to assess the answers throughout the study.

1. What percentage of graduates gets employment after completion of training?

2. What kind of employment is available in the labour market (wage employment or self-employment in the domestic market or employment in the foreign market)?

3. What is the average level of income of the employed graduates?

4. What opportunities and constraints are associated with the employment of graduates? Are all employed graduates satisfied with their job?

\section{METHODOLOGY}

Information for the study was collected from primary and secondary sources. The training graduates were met, interviewed and relevant documents produced by the Project were also reviewed.

\section{Selection of Sample Respondents}

Samples were drawn list of the trainees from the vocational training programs in Solar PV Technician and Mason conducted through the training providers in lastyears20122015. The training was conducted for 390 hours in different time cycles where the training was organized invarious places and villages of different six districts irrespective of gender and ethnicity. Under this project one of the training providers who conducted training for 400 youths in Solar PV Technician and 500 youths in Mason occupation was selected to carry out the study. From the sampling 103 graduates $(25.75 \%)$ in Solar PV Technician and 133 graduates $(26.6 \%)$ in Mason were selected for the study as made available by the training provider by using simple random sampling technique. Vocational training graduates were directly contacted and interviewed with the welldeveloped questionnaire. Interview with 25.75 percent and 26.6 percent of graduates that trained in Solar PV Technician and Mason conducted and obtained data and information were processed. The analysis is largely based on the data and information obtained from direct interviews.

\section{Data Collection}

Six enumerators were trained on data collection method and conducting interview before to assign them the job. After training they were depute done in each of the six selected districts to collect relevant primary data and information. The enumerators conducted direct interviews with the randomly selected VET graduates, and also collected information from the institution where they were trained. Coordination was made with the Research and Information Division of CTEVT, concerned training provider and employers in regard to this study.

\section{Data Processing and Analysis}

Qualitative data was synthesized in view of their relevance to the components related to the study. Quantitative data was processed by entering them into the computer. Frequency tables were produced in SPSS and Excel and then converted into word for the preparation of report. Both qualitative and quantitative information are blended in the report as per their relevance in substantiating the observations.

\section{Discussion and Interpretations}

A total of 236 training graduates of two distinct occupations (103 Solar PV Technician and 133 Mason) have participated and responded to the interview. The respondent's gender wise response in different occupation is as presented in the table- 1 below. 
Table.1: Distribution of Respondent Graduates by Gender

\begin{tabular}{|l|r|r|r|r|r|r|}
\hline \multirow{2}{*}{ Gender } & \multicolumn{2}{|c|}{ Solar PV Tech. } & \multicolumn{2}{c|}{ Mason } & \multicolumn{2}{c|}{ Total } \\
\cline { 2 - 8 } & Frequency & Percent & Frequency & Percent & Frequency & Percent \\
\hline Male & 77 & 74.76 & 82 & 61.65 & 159 & 67.37 \\
\hline Female & 26 & 25.24 & 51 & 38.35 & 77 & 32.63 \\
\hline Total & 103 & 100 & 133 & 100 & 236 & 100 \\
\hline
\end{tabular}

The table above clearly indicates the gender inclusion in the training and employment programs. Out of the interviewed 236 graduates, 67.37 percent were male respondents whereas 32.63 percent graduates were female. The data shows that there is higher percent of the male in the skill development programs in comparison to female.
The study attempted to identify the age wise participation of the youth in the training programs. Most of the skill development programs were specially targeted to the youth from age 15 to 50 and their participation found is presented as below.

Table.2: Distribution of Respondent Graduates by Age group

\begin{tabular}{|l|r|r|r|r|r|r|}
\hline \multirow{2}{*}{ Age groups } & \multicolumn{2}{|c|}{ Solar PV Tech. } & \multicolumn{2}{c|}{ Mason } & \multicolumn{2}{c|}{ Total } \\
\cline { 2 - 7 } & Frequency & Percent & Frequency & Percent & Frequency & Percent \\
\hline Between 15-20 years & 38 & 36.89 & 23 & 17.29 & 61 & 25.85 \\
\hline Between 21-30 years & 55 & 53.40 & 95 & 71.43 & 150 & 63.56 \\
\hline Between 31-40 years & 9 & 8.74 & 15 & 11.28 & 24 & 10.17 \\
\hline Between 41-50 years & 1 & 0.97 & 0 & 0.00 & 1 & 0.42 \\
\hline Total & 103 & 100.00 & 133 & 100.0 & 236 & 100 \\
\hline
\end{tabular}

The table- 2 above indicates that majority of the graduates belongs to 21 to 30 years age group in both occupations which counts 63.56 percent of total graduates. Their percentage counts to 71.43 percent of 21-30 years for the graduates who have attended the vocation on mason and about 53.40 percent years for the Solar PV vocation.The second largest group of graduates from age 15-20 years participated in the training that counts 36.89 percent in Solar PV and 17.29 percent in Mason respectively. The third largest population of the interviewed graduates belongs to 31-41 year of age group that counts 8.74 percent in Solar PV and 11.28 percent in Mason respectively. Only one graduate in Solar PV from age group of 41-50 years participated in the training. This indicates that skill development programs have participated the targeted youth. Similarly, the skill development and employment programs are targeted to the low education and school dropout youths in the country. The study attempted to identify the status of the education among the training graduates and the finding is presented in the table- 3 below.

Table.3: Distribution of Respondent Graduates by their Level of Education

\begin{tabular}{|l|r|r|r|r|r|r|}
\hline \multirow{2}{*}{ Education level } & \multicolumn{2}{|c|}{ Solar PV Tech. } & \multicolumn{2}{c|}{ Mason } & \multicolumn{2}{c|}{ Total } \\
\cline { 2 - 7 } & Frequency & Percent & Frequency & Percent & \multicolumn{1}{l|}{ Frequency } & Percent \\
\hline Illiterate & 0 & 0.00 & 1 & 0.75 & 1 & 0.42 \\
\hline Literate & 2 & 1.94 & 12 & 9.02 & 14 & 5.93 \\
\hline Grade 1-5 & 9 & 8.74 & 34 & 25.56 & 43 & 18.22 \\
\hline Grade 6-7 & 8 & 7.77 & 6 & 4.51 & 14 & 5.93 \\
\hline Grade 8-9 & 61 & 59.22 & 57 & 42.86 & 118 & 50.00 \\
\hline Test Pass & 15 & 14.56 & 18 & 13.53 & 33 & 13.98 \\
\hline SLC and Above & 8 & 7.77 & 5 & 3.76 & 13 & 5.51 \\
\hline Total & 103 & 100.0 & 133 & 100.0 & 236 & 100 \\
\hline
\end{tabular}


As presented in the table above, the data revealed thatout of the total interviewed graduates for both occupations, majority of the graduates (altogether 50 percent) were having their education grade 8-9. The second largest interviewed graduates' population counts to almost 14.56 percent in Solar PV who have completed their test pass examination and 25.56 percent graduates in Mason who have completed grade 1 to 5 . These data indicates that the programs are successful to provide services to the targeted youth.

The study also attempted to identify the employment status of the graduate participants before they attend the skill training and their response is presented in the table- 4 below.

Table.4: Occupational Status of the Graduates Prior to Training

\begin{tabular}{|l|r|r|r|r|r|r|}
\hline \multirow{2}{*}{ Occupational Status } & \multicolumn{2}{|c|}{ Solar PV Tech. } & \multicolumn{2}{c|}{ Mason } & \multicolumn{2}{c|}{ Total } \\
\cline { 2 - 7 } & Frequency & Percent & Frequency & Percent & Frequency & Percent \\
\hline Study & 6 & 5.83 & 8 & 6.02 & 14 & 5.93 \\
\hline Agriculture & 35 & 33.98 & 38 & 28.57 & 73 & 30.93 \\
\hline Jobless & 62 & 60.19 & 87 & 65.41 & 149 & 63.14 \\
\hline Total & 103 & 100 & 133 & 100 & 236 & 100 \\
\hline
\end{tabular}

The data above indicated that prior to their training the employment and other job related status of the respondent graduates under different categories. Out of the total surveyed graduates majority $(63.14 \%)$ responded that they were doing nothing and regarded themselves as jobless. Another 30.93 percent of the interviewed graduates have informed that they are involved in various types of agriculture work. Almost five percent of the graduates have informed that they were studying in their respective schools and negligible numbers of graduates were employed before participating the training. It also supports that the programs are targeted to the unemployed youths and the focusis in generating employment.

Satisfaction level of the graduates on the part of imparted skills is also necessary to identify their perception on the skills that has been able to learn from the training. VET graduates were asked to response about the achievement after they completed the training courses under skills for employment programs and the responses are as presented in the table- 5 below

Table.5: Response of the Graduates Regarding Training Achievement

\begin{tabular}{|l|r|r|r|r|r|r|}
\hline \multirow{2}{*}{ Quality of the Training } & \multicolumn{2}{|c|}{ Solar PV Tech. } & \multicolumn{2}{c|}{ Mason } & \multicolumn{2}{c|}{ Total } \\
\cline { 2 - 7 } & Frequency & Percent & Frequency & Percent & Frequency & Percent \\
\hline $\begin{array}{l}\text { Learnt almost all required } \\
\text { skills }\end{array}$ & 89 & 86.41 & 127 & 95.49 & 216 & 91.53 \\
\hline Learnt few skills only & 13 & 12.62 & 6 & 4.51 & 19 & 8.05 \\
\hline Nothing has been learnt & 1 & 0.97 & 0 & 0.00 & 1 & 0.42 \\
\hline Total & 103 & 100 & 133 & 100 & 236 & 100 \\
\hline
\end{tabular}

The data above indicated that majority of the graduates (91.53 percent)out of the interviewed have responded that they were able to learn all the necessary skills related to their vocations. Similarly, more than 8.05 percent of the graduates have indicated that they were able to learn. Only some of the skills those are required to perform their respective vocations. Only one graduate in Solar PV reported that $\mathrm{s} /$ he has learnt nothing.

As per the obtained data and information, majority of the trained graduates were satisfied with the skill and knowledge which they received from the training. $(86.31 \%)$ belonging to Mason have perceived that they have been able to learn all the needed knowledge and skills related to their vocation.Similarly $95.49 \%$ of the respondent graduates of Solar PV Technician occupation have respond that the skills and knowledge was helpful for them to establish in the employment.

As the major objective of the skill development training programs were to generate employment (Self or wage employment) and the training graduates adjustment in the labor market. The study therefore attempted to identify the employment status of the graduates and the response is presented in the table- 6 below. 
Table.6: Employment Status of the Graduates

\begin{tabular}{|l|r|r|r|r|r|r|}
\hline \multirow{2}{*}{ Employment Status } & \multicolumn{2}{|c|}{ Solar PV Tech. } & \multicolumn{2}{c|}{ Mason } & \multicolumn{2}{c|}{ Total } \\
\cline { 2 - 7 } & Frequency & Percent & Frequency & Percent & Frequency & Percent \\
\hline Self-employed & 66 & 64.08 & 89 & 66.92 & 155 & 65.68 \\
\hline Employed (Wage) & 21 & 20.39 & 12 & 9.02 & 33 & 13.98 \\
\hline Unemployed & 16 & 15.53 & 32 & 24.06 & 48 & 20.34 \\
\hline Total & 103 & 100 & 133 & 100 & 236 & 100 \\
\hline
\end{tabular}

As indicated by the data above, the present employment status among the total interviewed graduates is quite encouraging. The studied occupation areas havefound greater potentialities to generate huge number of self and wage employment opportunities in the labour market. Altogether 84.47 percent graduates in Solar PV and 75.94 percent graduates in Masonreported that they are employed in self and wage respectively. Analysis of the primary data generated for the study shows that about 65.68 percent of the interviewed graduates out of total graduates have secured self-employment in the labour market. Similarly, the numbers of wage employed graduates is also relatively high which count to 13.98 percent. Out of total interviewed graduates, about 15.53 percent graduates of Solar PV and 24.06 percent graduates have identified themselves under unemployed category.

One of the major objectives of the skill development program is to capacitate the youth for self-employment. In this prospect the programs are quite successful because about65 percent of the training graduates have responded their engagement in self-employment.

Similarly, the programs have also focused to social inclusion, awareness creation, mainstreaming and capacitate the females through increasing their participation in the non-traditional occupations. The table below presents the inclusion status in the VET programs.

Table.7: Employment status by Gender

\begin{tabular}{|c|c|c|c|c|c|}
\hline \multirow[b]{2}{*}{ Trades \& Gender } & \multicolumn{2}{|c|}{ Self Employed } & \multicolumn{2}{|c|}{ Wage Employed } & \multirow{2}{*}{$\begin{array}{c}\text { Total } \\
\text { No }\end{array}$} \\
\hline & No. & $\%$ & No. & $\%$ & \\
\hline \multicolumn{6}{|l|}{ Solar PV Tech. } \\
\hline Male & 56 & 63.64 & 16 & 18.18 & 72 \\
\hline Female & 11 & 12.50 & 5 & 5.68 & 16 \\
\hline Total & 67 & 76.14 & 21 & 23.86 & 88 \\
\hline \multicolumn{6}{|l|}{ Mason } \\
\hline Male & 55 & 54.46 & 8 & 7.92 & 63 \\
\hline Female & 34 & 33.66 & 4 & 3.96 & 38 \\
\hline Total & 89 & 88.12 & 12 & 11.88 & 101 \\
\hline
\end{tabular}

The table above on gender wise employment indicated that higher numbers of male graduates were employed in comparison to male graduates in both vocations. Analysis of trade-wise employment shows that higher percent of male graduates in both occupations are employed in selfemployment and significant number of female
graduates.Solar PV Technician graduateswere also employed in self -employment. The data further indicated that there is more chances to support gender and social inclusion through vocational education and trainings in labor market.

Table.8: Monthly Income of the Employed and Self-employed Graduates

\begin{tabular}{|l|r|r|r|r|r|r|}
\hline \multirow{2}{*}{ Monthly Income } & \multicolumn{2}{|c|}{ Solar PV Tech. } & \multicolumn{2}{c|}{ Mason } & \multicolumn{2}{c|}{ Total } \\
\cline { 2 - 7 } & Frequency & Percent & Frequency & Percent & Frequency & Percent \\
\hline Less than Rs. 5000 & 16 & 18.18 & 6 & 5.94 & 22 & 11.64 \\
\hline Between Rs. 5001-8000 & 64 & 72.73 & 60 & 59.41 & 124 & 65.61 \\
\hline
\end{tabular}




\begin{tabular}{|l|r|r|r|r|r|r|}
\hline Between Rs. 8001-11000 & 8 & 9.09 & 30 & 29.70 & 38 & 20.11 \\
\hline More than Rs. 11001 & 0 & 0.00 & 5 & 4.95 & 5 & 2.65 \\
\hline Total & 88 & 100 & 101 & 100 & 189 & 100 \\
\hline
\end{tabular}

Observation of the effectiveness of the training, graduates were asked to provide the tentative range of their present monthly incomes. Out of the total employed or selfemployed graduates, the majority of graduates or almost 65.61 percent of the graduates have indicated that their monthly income range stands between NRs. 5,001 to $8000 /$ month. Another20.11 percent of the total employed and self-employed graduates the total monthly income range comes between NRs 8,001 to 11,000/month. Almost twelve percent graduates have placed their monthly income less than NRs. 5000 and 2.65 percent graduates reported that they earn over NRs. 11,000/month.

A comparative analysis on the range of monthly income of the employed and self-employed graduated for the studied two vocations could be seen within the similar pattern and scales. There is also an individual and social aspect associated with the economic growth which is the positive feeling and satisfaction with the work and individual is performing. Assessing the satisfaction, the respondent training graduates were asked and their response is presented as below.

Table.9: Level of Satisfaction with Work and Income

\begin{tabular}{|l|r|r|r|r|r|r|}
\hline \multirow{2}{*}{ Satisfaction } & \multicolumn{2}{|c|}{ Solar PV Tech. } & \multicolumn{2}{c|}{ Mason } & \multicolumn{2}{c|}{ Total } \\
\cline { 2 - 8 } & Frequency & Percent & Frequency & Percent & Frequency & Percent \\
\hline Yes & 79 & 89.77 & 97 & 96.04 & 176 & 93.12 \\
\hline No & 9 & 10.23 & 4 & 3.96 & 13 & 6.88 \\
\hline Total & 88 & 100 & 101 & 100 & 189 & 100 \\
\hline
\end{tabular}

While assessing the present level of satisfaction on the part of their work and income, the graduates were asked to acknowledge their monthly income and the status they have maintained in the society. The analysis of the available data indicates that about 93.12 percent of the total interviewed graduates have shown their satisfaction with present job and income. Only a small percentage or about 6.88 percent graduates have shown their dissatisfaction with the present work and level of monthly income.

\section{MAJOR FINDINGS}

Majority of the graduates belong to 15 to 30 years age group where their population size counts to almost89.41 percent of the total interviewed graduates. Out of the interviewed graduates about 80 percent have their education under SLC ranging from literate grade ten of school education. Majority of the surveyed graduates belong to Janajati caste group where their Proportion counts to 41.54 percent of the total interviewed graduates. The population of graduates belonging to Dalit and Brahmin/Chettrigroups count to 36.44 percent and 21.61 percent respectively. Though the majority of the interviewed graduates 74.15 percent do not have encountered any social and physical deprivation status, almost one-fourth of the interviewed graduates have identified themselves as domestic helpers prior to attending the training. Majority of the graduates (63.14 percent)prior to attending the training have informed that they considered themselves as jobless. Another 30.93 percent were involved in various types of agriculture work whereas after completing the skill training majority (more than 80 percent) were found engaged in the employment which shows that skill programs are instrumental to generate employment in Nepal.

The Key findings from the study as per the focused research questions are as below.

1. Majority of the interviewed graduates were found employed after they receive vocational training. Altogether 72 percent graduates in Solar PV Technician and 63 percent in Mason were found employed after they complete the skill training in respective occupations.

2. Majority of the respondent VET graduates were found employed in self-employment followed by wage employment. The data revealed 84.4 percent graduates of Solar PV Technician and 75.94 percent graduates of Mason have informed that they were wage or selfemployed in the labour market. More specifically out of the total respondents about 76 percent and 24 percent were employed in self and wage employment 
respectively. Similarly, in case of the Solar PV Technician this is 88 and 12 percent respectively.

3. As revealed by the obtained data, almost 65.61 percent of the graduates have indicated that their monthly income range stands between NRs. 5,001 to 8000 /month. Another 20.11 percent of the total employed and self-employed graduates the total monthly income range comes between NRs 8,001 to 11,000/month. Almost twelve percent graduates have placed their monthly income less than NRs. 5000 and 2.65 percent graduates reported that they earn over NRs. 11,000/month.

4. Significant numbers of the interviewed graduates (98.41 percent) have indicated that their present job is very much related to the occupation they were trained. Similarly, majority of the interviewed graduates (93.12 percent) were satisfied with their present level of monthly income.Majority of the interviewed graduates (73.73 percent) have indicated that they satisfied with their present job. Another 21.19 percent graduates have shown interest to participate in advance level trainings to scale up their knowledge, skills and earning.

\section{CONCLUSION}

The Skills for Employment programs in Nepal seems reasonably successful in ensuring employment after training through the mobilization of private training providers. The analysis of the primary data generated for the study indicates that the surveyed two occupations, i. e., Solar PV Technician and Mason provide a satisfactory performance in the labour market. It has been observed that about84.47 percent graduates of Solar PV Technician and 75.94 percent graduates of Mason of the total interviewed graduates have been able to get employment in the labour market. Analysis of the primary data generated for the study shows that altogether65.68 percent of the interviewed graduates have secured self-employment in the labour market. The numbers of wage-based employed is relatively small which count to only about 13.98 percent. The data indicate that these occupations are more labor market friendly trades where potentiality of self-employment is higher.

The higher number of self and wage employed graduates indicates the higher potentialities of the occupations in the overall labour market. The nature and employability of those occupations have greater chances to generate primarily self-employment opportunities in the labour market. The partner training providers of skills development programs has invested considerable efforts to plan, organize and market the training events. Selection of appropriate and employment based occupation for the local markets along with selection of appropriate trainees (gender, ethnic and caste groups, age group, and level of educational attainment) also indicates that the training was conducted by following a planned systematic approach.

Increasing self-employment of the vocational training graduates contribute to enhance the sustainable development and to encourage self-employment the graduates of the programs should be facilitated with soft loans/micro credit for a start. However, there isthe need to conduct market studies and revise curriculum by linking them closely to the needs of the labour market.It is also felt needto collaborate with the employers to increase the wage employment of the trained graduates.

\section{REFERENCES}

[1] CTEVT. (2012). Tracer Studies of the Market Oriented Short Term Skill Training (MOST) Graduates. Bhaktapur: Skills for Employment Project (SEP).

[2] CTEVT. (2016). Annual Report of Council for Technical Education and Vocational Training (CTEVT). Bhaktapur: Research and Information Division.

[3] Durkheim, E. (1915). On Education and Society. In E. Durkheim, Educational Transformation (p. 2334).

[4] GON, G. o. (2012). National Technical and Vocational Education and Training Policy. Kathmandu: Ministry of Education.

[5] GON, G. o. (2015). A Report on Social Statistics of Nepal. Kathmandu: Ministry of Women,Children and Social Welfare.

[6] GON, G. o. (2015). Economic Survey. Kathmandu: Ministry of Finance.

[7] Mane, P. (2014). The Scope of Skill Development through Vocational Training and it's Impact on the Economic Development of India. Tactful Management Research Journal, 127-129.

[8] MOE, M. o. (2015). Educational Information: Nepal. Kathmandu: Information Division, MOE.

[9] MOE, M. o. (2016). Project Document:Enhanced Skills for sustainable and Rewarding Employment (ENSSURE). Bhaktapur: Council for Technical Education and Vocational Training (CTEVT).

[10] Sen, A. (1983). The Quality of Life: Capabilities and Well-Being. Oxford Scholarship Online, 96-109.

[11] Sharma, T. (2008). Connecting Technical and Vocational Education and Training (TVET) with Employment in Nepal: Current Problems, Issues and Trends. Technical Education and Vocational Training Journal, 1-12. 
[12] UNESCO. (2012). Transfering Technical and Vocational Education and Training (TVET): Building Skills for Work and Life: Third International Congress on Technical and Vocational Education. Paris: UNESCO-UNEVOC.

[13] Visscher, A. (2009). Improving Quality Assurance in European Vocational Education and Training. Springer.

[14]Zgaga, P. (2005). The Importance of Education in Social Reconstruction. Slovenia: Center for Education Policy Studies. 